\title{
Kernos
}

Revue internationale et pluridisciplinaire de religion grecque antique

32 | 2019

Varia

\section{Causal explanation of disease in the iamata of Epidauros}

\section{Hedvig von Ehrenheim}

\section{(2) OpenEdition \\ Journals}

\section{Electronic version}

URL: https://journals.openedition.org/kernos/3125

DOI: 10.4000/kernos.3125

ISSN: 2034-7871

\section{Publisher}

Centre international d'étude de la religion grecque antique

\section{Printed version}

Date of publication: 1 December 2019

Number of pages: 101-118

ISBN: 978-2-87562-229-7

ISSN: 0776-3824

\section{Electronic reference}

Hedvig von Ehrenheim, "Causal explanation of disease in the iamata of Epidauros", Kernos [Online], 32 । 2019, Online since 01 October 2021, connection on 15 February 2023. URL: http:// journals.openedition.org/kernos/3125 ; DOI: https://doi.org/10.4000/kernos.3125

This text was automatically generated on 1 February 2022.

All rights reserved 


\title{
Causal explanation of disease in the iamata of Epidauros
}

\author{
Hedvig von Ehrenheim
}

I wish to thank Niko Arvanitis and Maria Mili for insightful readings of the text, and suggestions for ameliorations. I further wish to thank the Uppsala University Classical Archaeology seminar for valuable comments and discussions, and in particular Brita Alroth, Susanne Berndt, Gunnel Ekroth, Kerstin Höghammar, and Lars Karlsson. I also wish to warmly thank the anonymous peer-reviewers of Kernos, as well as to Vinciane Pirenne-Delforge for careful reading and suggestions for ameliorations. Any faults remain of course my own.

\section{Introduction}

1 In ancient Greece, illnesses might be explained as the result of a number of different causes - pollution, natural causes, morally bad behaviour, and divine vengeance being among them. ${ }^{1}$ A current scholarly hypothesis is that illnesses in ancient Greece were at first believed to be caused by the anger of the gods, in time evolving into a more rational approach to disease, seeing its aetiology as natural. This change would be due to the rise and expanding popularity of the Greek art of medicine. ${ }^{2}$

2 Hand in hand with the hypothesis of rationalization we find the hypothesis of internalization. This model that a fatalistic view on the cause of disease, as sent by the gods, became internalized, so that it came to be believed that your own choices and actions, not the will of the gods, caused disease. ${ }^{3}$ This notion was connected to a general internalization of emotions, as discussed by E.R. Dodds. He argued that Greece in the Archaic period moved from being a shame culture to becoming a guilt culture. ${ }^{4}$ According to R. Pettazzoni, and following him, A. Bendlin, the feeling of guilt as a phenomenon is a universal occurrence, and seems difficult to see as the product of a social evolution. ${ }^{5}$

3 This article is an attempt argue that perceptions of the cause of disease have been multi-explanatory all through ancient Greek history. In particular, as a case study, I will examine the collection of healing inscriptions, iamata, of Epidauros, which have an 
underestimated heuristic potential on the different ideas related to the cause of disease among the worshippers of Asklepios at the time. The iamata (literally "remedies") are 70 narratives collected, edited, and inscribed around $350 \mathrm{BC}$ on four large stones slabs and set up in the sanctuary of Asklepios at Epidauros for all to read, possibly to convince the worshippers of the healing power of the god, and inspire new healings. ${ }^{6}$ According to LiDonnici's stylistic analysis, some of the testimonials presumably date back to c. $450 \mathrm{BC}$, and the latest ones probably come close to the editing and inscribing of the stelae in $350 \mathrm{BC} .^{7}$ The chosen case study thus limits my investigation to the Classical and Hellenistic Greek world, and in particular to the cult of Asklepios.

K. Latte ${ }^{8}$ and A.D. Nock ${ }^{9}$ have argued for the presence of detailed confessions of guilt in the iamata of Epidauros. F. Kudlien agrees that some of the iamata give us evidence of early Greek confessions, but writes that these are indeed the only examples in the cult of Asklepios for such an otherwise non-Greek mentality. ${ }^{10}$ Most importantly, though, the Edelsteins established the cult of Asklepios as an early representative of a focus on the individual and on the importance of purity, when approaching the divine, not only of the body but also of the mind. ${ }^{11}$

5 Sacred laws emphasizing the importance of entering the sanctuary with both a ritually pure body as well as a pure mind appear in late Hellenistic times. ${ }^{12}$ There is, notably, no inscription which antedates late Hellenistic or Roman times, apart from, possibly, the

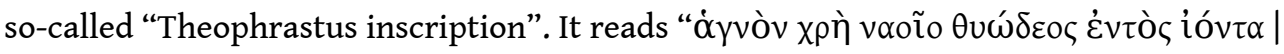

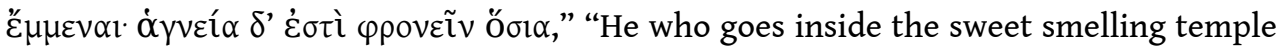
must be pure. Purity is to think pious thoughts." ${ }^{13}$ It was believed to have been displayed at Epidauros and to date to the $4^{\text {th }}$ century $\mathrm{BC}$, as Theophrastus, who allegedly referred to the inscription, lived then. This quote, entailing a reference to the inscription, is found in the much later De Abstinentia (2.19) by Porphyry, who is supposedly citing Theophrastus' work On Piety. J. Bremmer has, convincingly in my opinion, shown that the text is not a quote of Theophrastus, and so cannot have this early date. ${ }^{14}$ The importance of having a pure mind when praying to Asklepios, and not primarily to please the god with expensive donations, would then rise, but not be the rule, in Hellenistic times. ${ }^{15}$

\section{Co-existing aetiologies of disease}

Before we move on to the Epidaurian iamata, we will have a short look at which different aetiologies of disease existed in Classical Greece, in order to contextualize the miracle stories properly.

7 Firstly, pollution (miasma) appears as an explanation in the case of skin diseases. ${ }^{16}$ Although purifications were a common treatment of disease (not only skin disease), pollution as an aetiology does not appear in the literary evidence. For instance, none of the sacred laws concerning polluted persons banned from entering a temple included the diseased. ${ }^{17}$ On the other hand, purification performed by popular purifiers was one of the most common healing techniques in both Archaic and Classical times, and the underlying reason for purifications in healing might have been that disease was assimilated to dirt which could be washed off. ${ }^{18}$

8 Secondly, disease could be perceived as caused by an angered god. The classical example in Greek literature of a god causing illness appears in the Iliad 1.37-54, where 
Apollo sends a plague. ${ }^{19}$ After the outbreak of plague the whole army is purified (Il. 1.314-317, $\dot{\alpha} \pi \circ \lambda u \mu \alpha i ́ v \varepsilon \sigma \theta \alpha 1$ used), probably in salt water as the sea was close, whereupon a sumptuous sacrifice is offered to Apollo. ${ }^{20}$ The Greeks discover the cause of the god's wrath not to be, as expected by Achilleus, a forgotten vow or sacrifice (1.65-67), but the calling upon Apollo by Chryses to revenge the wrong done him and his daughter. This is, however, the only passage in Homer's works where illness or pain is associated with the gods, and notably the disease chosen for a punishment strikes on an epic scale. ${ }^{21}$ Sacrifice (preceded by a purification) clearly was the way of appeasing the angered Apollo. ${ }^{22}$

9 Thirdly, the perception existed that unethical or immoral behaviour might cause disease. Thebes was struck by the plague in Edipus Tyrannus (22-39), in response to its kings' misdeeds. In the events that unfold in the myth, Oedipus had not wronged a god, but broken a social taboo. ${ }^{23}$ Here, as in the Iliad, a whole group is affected (the army of the Greeks and the city of Thebes), and the cause of this major catastrophe is seen as divine. Oedipus is in the end a victim of a divine prophecy, so the cause of the plague should not be taken as commonplace. The royal families of tragedy in a way carry their misfortunes and diseases in their fate, inherited at birth. ${ }^{24}$ They are not people with whom the spectators would easily identify, and we cannot expect that an Athenian shoemaker watching the play would think that his particular illness was caused by the gods in the same way.

However, if not one particular god's anger was the cause of a disease, then a divine factor might somehow be seen as punishing those who had opposed social laws and morality by sending a disease. ${ }^{25}$ In a possible fragment of Aristophanes' Heroes the chorus says "We are the guardians of good things and ill; we watch out for the unjust, for robbers and footpads, and send them diseases (spleen, coughs, dropsy, catarrh, scab, gout, madness, lichens, swellings, ague, fever). That's what we give to thieves...". ${ }^{26}$ Here it is the unjust, criminals who have offended social laws, who are punished with disease by divinities.

11 Fourthly, there existed, already from Archaic times, the belief that the aetiology of disease was natural. ${ }^{27}$ The Hippocratic On the Sacred Diseas ${ }^{28}$ states that since the divine

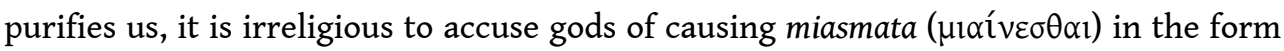
of diseases..$^{29}$ The author of On the Sacred Disease further argues that all diseases have natural causes (as well as in a way being divine, as nature is divine), but that no particular god can be held responsible (as done by the itinerant purifiers who are the target the author wishes to discredit). ${ }^{30}$ This idea is presented also in the Hippocratic On Ancient Medicine. ${ }^{31}$ This perception of the causality of disease as natural can in fact be seen already in the Odyssey (11.198-201), where the wasting disease is described as a hateful state, not caused by any god, but just as a matter of fact. Furthermore, Hesiod in Work and Days (101-104) describes the diseases set free by Pandora, in effect describing them as bestowing misfortune on men by their own accord. ${ }^{32}$ As disease in the ancient world was ubiquitous, and cures mostly lacking, ascribing a particular god to every disease would simply be impractical.

Four different, co-existing aetiologies of disease can thus be discerned in the ancient Greek world. Which take on disease was then chosen in the cults of the healing gods, supplying the needs of worshippers with common diseases, such as oedema and infected wounds? We have seen that Apollo, considered the prime healer in Archaic times, could cause disease. ${ }^{33}$ The cult of his doctor son, Asklepios, sprung forth from the 
cult of Apollo. ${ }^{34}$ Asklepios was also the patron of Hippocratic physicians, and many of his cures were reminiscent of Hippocratic cures (further on this below). This background might make for an interesting take on the cause of disease in his cult. Furthermore, as the Late Classical period has been suggested in previous research as introducing a change of mentality surrounding the notions of purity and guilt and their possible connection to disease, what better material to analyse than the iamata of Epidauros.

\section{The iamata of Epidauros and aetiology of disease}

\section{The texts of the iamata}

Before examining the iamata, we need to answer the question: do they reflect the perceptions of the afflicted either by straightforward remarks, or as preconceived notions? The iamata, as discussed by Dillon and LiDonnici, had the purpose of establishing the power of the god and to fill the worshippers with hope and expectations of what cures might be obtained. ${ }^{35}$ As Dillon has showed, a message to the worshippers is also put across to trust the powers of the god, and, of course, to pay the fees for the cure. In all likelihood, the iamata could only fulfil these purposes if the suppliants could identify themselves with the suppliants in these stories. If the helpseekers are to believe in the possibility of the miraculous, they had to relate to the people of the stories and their general background. Hence it is my view that the conceptions seen in the iamata concerning a cause of the illness would be close to what the suppliants were thinking themselves. As stated above, there are 70 narratives in total, of which 21 are too fragmentary to use in the analysis. ${ }^{36}$

In a few of the iamata, worshippers were punished by Asklepios, and this has been seen to support an argument for the cult of Asklepios commencing a shift in society towards a notion that moral behaviour affected the state of the body. The most important iamata in this respect are Echedoros of Thessaly (A7), Kaphisias (B36), and the fishmonger Amphimnastos (C47) ${ }^{37}$ Before we turn to these three, we must mention the fragmentary iamata $\mathrm{C} 54$ and C58, which have been put forward by Kudlien to support

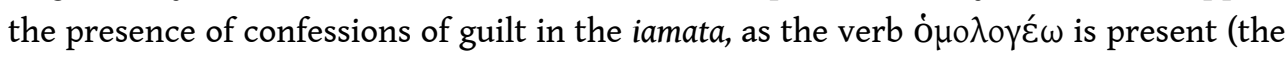
verb can be read in the inscription, but the surrounding sentence is gone). ${ }^{38}$ Herzog

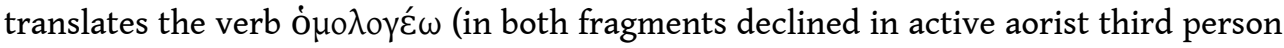
singular) as "gestand" ("he/she admitted"), ${ }^{39}$ whereas LiDonnici translates with "he/she

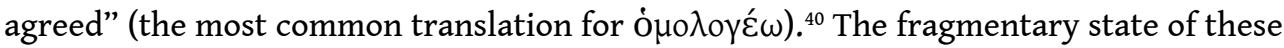
inscriptions makes it impossible to conclude what is agreed upon (or, possibly, admitted), and neither C48 nor C54 can be taken as any proof of the presence of confessions of guilt in the iamata.

There are seven iamata in the corpus of 70 iamata from Epidauros that show how the god punishes worshippers. Admittedly, not all of them have as strong a sense of the god punishing. They may be divided into describing two groups of people: firstly, those who do not observe the correct rules of worship, and secondly, people who are unbelievers and do not have faith in the miracles of Asklepios. ${ }^{41}$

16 To the first category belong iamata A7, A11, B22, and C47. In the iama A7 Echedoros had received money from Pandaros in order to make a dedication to Asklepios, but he failed to do so. In spite of this he went to the sanctuary and slept there. He saw Asklepios 
there in a vision, and upon being questioned he denied having received any money from Pandaros. Instead, he promised to have an image inscribed and dedicate it at the sanctuary should Asklepios cure him. The character of Echedoros' and Pandaros' ailments seems to have been the fact that they both had marks, or tattoos, on their foreheads. ${ }^{42}$ The god tied Pandaros' fillet around Echedoros, and told him to take off the fillet in the morning and wash his face at the fountain and look at his reflection in the water. Echedoros did as told, and he discovered that in addition to his own mark the god had added Pandaros'. A7, just as B22 below, are quite paradigmatic in revealing that Asklepios should always be given the promised payment for the cure. Of course, failing to do so might be seen as a moral fault, but the main message in this particular iama is that a cultic prescription should always be respected.

In iama A11 Aischines broke the rules and spied on the incubants sleeping in the abaton: he climbed up a tree and looked over into the abaton. He fell down from the

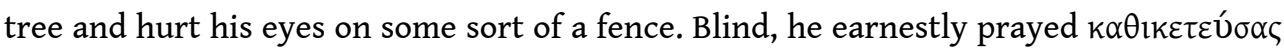
to the god, and after having slept in the abaton he became well. Another example of disrespect towards the god is the story of Hermon of Thasos, B22. He came to Epidauros

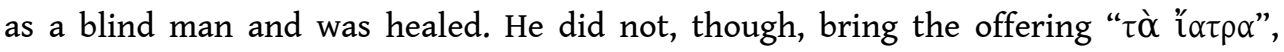
wherefore the god made him blind again. He came back with the promised offering and was restored to health anew.

The last example, C47, tells of the fishmonger Amphimnastos, who swore to bring a tenth of his profit to Asklepios, but failed to do so. When he was selling fish on the agora in Tegea the fish were suddenly struck by lightning, and were burned. People gathered and Amphimnastos made clear his deception against Asklepios (...

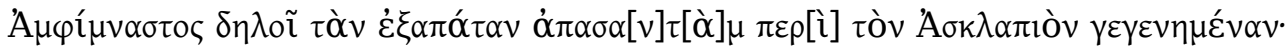

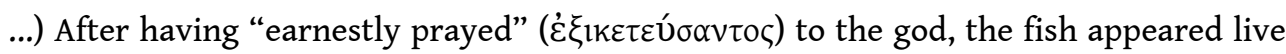
again, and he dedicated the tenth part of his profit as promised to Asklepios.

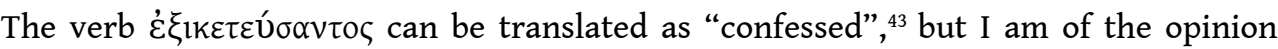
that $\delta \eta \lambda$ oi is better intended in the broader sense "to make known", as "confessed" admittedly does not fit the context, as it strongly carries modern cultural connotations and concerns. The iama would not make sense if the people in the square were not told why the fish burned, and then again, why they came back to life again. Further, when Amphimnastos tells his story the god's power is made clear and the importance of following the cult rules conveyed.

Iamata A3, A4, and B36 belong to the category of unbelievers. In the iama A3 a man who was paralysed in all his fingers except one came to the god. When he was looking at the plaques in the sanctuary he didn't believe the cures. As expected, when he incubated he felt that he sat below the temple and played knucklebones, when the god came to him and stretched out his fingers, whereupon they were cured. The god asked him if he still did not believe in the inscriptions around the sanctuary, and he answered "no". The god replied that since he did not believe in them before, he should be called "Unbeliever" ("A

21 Further, in iama A4 Ambrosia from Athens arrived in the sanctuary, being blind in one eye. She ridiculed some of the cures set up in the sanctuary as being impossible. The god came to her in a dream, and asked her to set up a silver pig in the sanctuary as a memorial of her ignorance. Thereupon he made her well again. Last, in the fragmentary B36 we meet Kaphisias, who laughed at the treatments of Asklepios. He was consequently injured in his foot in a riding accident, but after having earnestly 


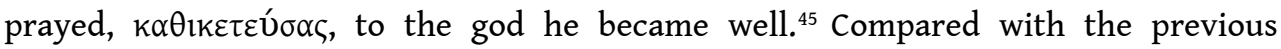
examples of Unbelievers, it would seem that it was graver to laugh at the god's power than just not to believe in them. Another iama, which involves both a non-believer and a believer, is A10, where a baggage-carrier on his way into the sanctuary falls and ampng other things his master's drinking-cup gets broken. He tries to put it back together again, but a passer-by says that not even Asklepios at Epidauros could mend that cup. The baggage-carrier consequently walks into the sanctuary, and when he opens his bag again, the cup is whole (and is later dedicated to the god). The message here is clearly the same, as in the above quoted stories: not to doubt the god's miraculous powers. ${ }^{46}$

There seems thus to be no punishments by way of illnesses given by Asklepios on account of offences towards anyone but the god himself or given cultic rules. Either the people have not given the god what has been promised, or they do not believe in his ability to perform miracles. Hence these iamata are put up as a warning to people coming to the sanctuary: pay the god what has been promised and do not mock the miraculous healings. In any cult practice and ritual where miracles play a large part, there would always be someone not believing in the miracles (especially the most fantastic ones), or not paying up the fees. These stories are there to correct such behaviour. These are miracle stories that relate to punishments, but the reason for punishment is not a sin committed in society, and the punishment itself is not a symptom which necessarily reveals the trigger cause of the illness, i.e. a sin. In fact, and most telling, it can for instance be the burning of fish, in other words the punishment does not involve the patient himself (as seen in C47 above). Hence, these seven iamata do not primarily give the message to the worshippers to behave morally and be pure of mind, but rather to believe in the power of the god and to follow the cult rules. If we compare to another Unbeliever, Pentheus, the punishment profoundly affected him and his family, and there is no room for doubt of the severity of the offence. The iamata, on the other hand, reveal a much different interplay between worshippers and the divine: they enforce practical rules at the sanctuaries and regulations of the cult.

\section{Simulation of real medical cures in the iamata}

Most of the iamata do not give any information on the perceived cause of the disease. Hence, the prescribed cures do not reveal any indication that the ailments of the worshippers would have been considered as originating from wrongdoing. In some of the iamata there is, though, a clear connection between the illness and the cure: a lame man is asked to carry a large stone. ${ }^{47}$ Similarly, in A5, a mute boy speaks, when asked to answer the god. In iama A3, a man with paralyzed fingers had them straightened by Asklepios. This may suggest a notion that the joints needed to be turned into place, just as a Hippocratic doctor would do. Another parallel to medical cures is when Asklepios in A9 cured a man with an eye disease by mixing a drug and pouring it into his eyes, giving the impression of a natural cause of the problem. Similarly, in B40, a man with a wounded eye had it cured by Asklepios pouring a drug into it. In A12, a man with a spearhead stuck in his head had it removed by Asklepios (the cause of the problem thus being bad relations between humans, having nothing to do with the gods). B30 gives a similar story, where a barb was stuck in a man's lung and, severely festering, it fell out by itself after he slept in the abaton. A more remarkable story is B32, where a man with a spearhead stuck through both his eyes had it removed by Asklepios and regained his 
sight. All of these stories concerning injuries which are not disease stricto sensu and would not have fallen under the category of ailment caused by the god. One of the oldest branches of Greek medicine was surgery. Greek medicine was one of the big advocates for natural proto-scientific explanation of disease and hence its influence on the Epidaurian cures is of interest. ${ }^{48}$

Particularly interesting are a number of cases where Asklepios and his helpers operated on the incubants. In A13, a man with his abdomen full of leeches had them surgically removed by Asklepios, also here a clear reference to surgery by doctors. A woman with an intestinal worm had it surgically removed in a similar manner in B23. In B25 Sostrata, who likewise suffered from intestinal parasites, had an operation. In contrast, in B41 Asklepios removed intestinal parasites by giving the worshipper a drug to drink, which made her vomit. ${ }^{49}$ In all of these cases, the common ailment of intestinal parasites is treated as an affliction anyone might incur.

Continuing with a slightly different example, in A19, a bald man regained his hair when the god applied a drug. Not knowing how the Hippocratic school would have treated this aesthetical condition (if at all), the cause of the loss of hair was here perceived as curable by a medical drug anointed on the relevant part of the body: a natural cause. In B21, a woman with dropsy was cured by the god opening her body and letting out the excess fluid. This points to the perception of a natural cause, although doctors at the time were more likely to prescribe a diet or medications to evacuate water from the body, or more cautious surgical methods. ${ }^{50}$ In B27 a man with a sore was surgically cured by Asklepios and his assistants. The story is graphic and entails an operating table, a clear reference to worldly medicine ${ }^{51}$ Likewise, a man with a cancerous sore in iama $\mathrm{C} 66$ was cured by Asklepios removing the sore.

In three iamata we find possible prescriptions for taking a bath. ${ }^{52}$ One might think that points towards the bath being in essence a purification and hence the cause of the illness being some form of pollution. On the other hand, purifications were commonly administered as cures, most often without any pollution having first been identified as a cause for the disease, but just by habit and belief in the efficacy of the remedy. ${ }^{53}$ Further, baths were one of the most common prescriptions in worldly medicine, and the reason for giving different baths as a remedy is mostly explained as an attempt to regulate the bodily humours. ${ }^{54}$

Similarly, in a cure inscription from Lebena ${ }^{55}$ Asklepios ordered a woman to put burnt shell together with oil of roses, mallow, and olive oil on a wounded finger, thus curing her. Chaniotis has shown how burnt shell was known for healing in ancient medicine (Galen). ${ }^{56}$ Other Cretan iamata may also reflect prescriptions concerning food and diet. ${ }^{57}$ Further, the inscription of Aelius Theon, dating from Roman times and found in Pergamon, clearly shows the influence from medical diet on Asclepian cures: ${ }^{58}$ "For 120 days I have drunk nothing in the early morning, but have eaten fifteen corns of white pepper and half an onion, as the god ordered, and so I have clearly been saved from many and great dangers." ${ }^{59}$ The cures prescribed by Asklepios to Aelius Aristides further include the otherwise medical treatments of diet, poultices, blood-letting, and drugs.$^{60}$ Cécile Nissen has analysed the close relations existing between Hippocratic doctors and Asclepian cult, above all for Roman times but also as concerns Classical Greece. ${ }^{61}$

To sum up, when contextualizing the aetiology of disease of the Epidaurian cures, they best compare with the perceptions of worldly medicine and contemporary medical 
science. ${ }^{62}$ In other words, the most common causal explanation in the iamata is that of natural causes and most of the cures are influenced by medical cures. In the few miracles where worshippers are punished with an illness, it is the same illnesses with which they arrived, ${ }^{63}$ but were re-given after the cure, as they had not paid the healing fee.

\section{Concluding remarks}

natural) might be looked for in the context of the event. If a phenomenon is ubiquitous, there is no point in searching for a particular cause, other than that this is part of everybody's lot. A sudden and unusual illness, or a disease such as the plague striking Athens under the Peloponnesian war, might more readily open up for searching for a particular cause or remedy that has to do with divine agency. It is important to remember, though, that the historical study of causal thinking in social groups can never arrive at disclosing one general type of causal reasoning for the whole group. There will always be different cultural communities within a society, ${ }^{64}$ and even within the group there will always be duality of beliefs, that is two contradictory explanations of an event or phenomenon can be accepted as equally true by the same individual..$^{65}$ Even though a development in Greek religion from late Hellenistic times (or earlier as argued by Petrovic and Petrovic) demands the pure mind of the worshipper, this does not have to effect or construct the lack of it as a cause of disease. As we have seen, it seems that there are many different explanations of disease at any given time. I would argue that causal reasoning of phenomena fills the needs of a society, group, or individual, and that these needs change with every given situation. Without many different ways of reasoning around causes of disease (including not taking any position at all), the historically known phenomenon of medical pluralism would not exist. In most societies, as scholars today agree upon, the opposition between "rational" versus "irrational" medicine (as traditionally framing historical development in the field of history of medicine), is more and more replaced by a historical model where the medical system is culturally constructed ${ }^{66}$ Medical pluralism (the use of several medical systems: conventional, complementary as well as alternative medicine) in societies is recognized, and different ways of studying it have been developed. ${ }^{67}$ Without a society encompassing many different and at times contradictory explanations on the cause of disease, there would not be medical pluralism.

31 The cause of disease as seen in the iamata was generally not reflected on, but for a few examples, where Asklepios gave back an illness to those who had not paid their fees, or disbelieved in his powers. As concerns guilt, and the confession of sins, the Greek context differs from e.g. Christian confession literature, where the words have a context of their own. Were the readers of the fisherman Amphimnastos' story supposed to understand that he felt guilt? As a universal feeling, certainly. But it was not the objective of the story to induce guilt in non-conforming worshippers. The priests at the 
sanctuary redacted the collection and put a message across to the worshippers not to distrust the god, and always to pay up the fees or there would be consequences.

Further, some of the cures given by Asklepios resemble cures in the Hippocratic texts. In some, an explanation of the disease in the form of the humoral theory might be guessed at, a possible influence from causal reasoning of the different authors of the Hippocratic corpus. In other iamata, such as the Roman one of Aelius Theon, diet is perceived as causing health or illness and apparently lies behind the prescribed cure. Most iamata, though, do not give any hint at what the cause of the ailment was perceived to be. My explanation would be that at such a big healing sanctuary as Epidauros, there was a need to be practical, and since illness was abundant people would not search for its causes all the time.

The larger evidence at hand on ideas on the cause of disease held in Greece of Classical and Early Hellenistic times, suggests that the choice of causal model (natural, divine, moral, miasma) could vary for the same group and illness, and that different types of explanations co-existed.

\section{BIBLIOGRAPHY}

ASSMAN, J., 'Confession in ancient Egypt', in J. ASSMAN, G.G. STROUMSA (eds.), Transformations of the inner self in ancient religions, Leiden et al., 1999 (Studies in the History of Religions, 83), p. 231-244. BARTON, J., 'Hippocratic explanations', in P.J. VAN DER EIJK (ed.), Hippocrates in context, papers read at the $X I^{\text {th }}$ International Hippocrates Colloquium, University of Newcastle upon Tyne, 27-31 August 2002, Leiden, 2005, p. 29-48.

BENDLIN, A., s.v. 'Sünde', HrwG 5 (2001), p. 125-134.

BOUDON, V., 'Le rôle de l'eau dans les prescriptions médicales d'Asclépios chez Galien et Aelius Aristide', in R. GINOUvÈs et al. (eds.), L'eau, la santé et la maladie dans le monde grec, Athens/Paris 1994 (BCH, suppl. 28), p. 157-168.

Bouffartige, J., Patillon, M. (eds.), Porphyre, De l'Abstinence, Paris, 1979.

BOURGEY, L., Observation et expérience chez les médecins de la collection hippocratique, Paris, 1953.

BREMMER, J., Greek religion, Oxford, 1994.

-, 'How old is the ideal of holiness (of mind) in the Epidaurian temple inscription and the Hippocratic oath?' ZPE 141 (2002), p. 106-108.

BURKERT, W., Greek religion, Cambridge, Mass., 1985.

BYNUM, W., History of medicine: a very short introduction, Oxford, 2008.

CARBON, J.-M., PIRENNE-DELFORGE, V., ‘Beyond Greek “Sacred Laws”', Kernos 25 (2012), p. 163-182.

CHANIOTIS, A., 'Illness and cures in Greek propitiatory inscriptions and dedications of Lydia and Phrygia', in P.J. VAN DER EIJK, H.F.J. HORTSMANSHOFF, P.H. SCHRIJVERS (eds.), Ancient medicine in its socio- 
cultural context. Papers read at the Congress held at Leiden University 13-15 April 1992, vol. 2, Amsterdam/Atlanta 1995, p. 323-344.

-, 'Reinheit des Körpers - Reinheit des Sinnes in den griechischen Kultgesetzen', in J. ASSMAN, T. SUNDERMEYER (eds.), Schuld, Gewissen und Person. Studien zur Geschichte des inneren Menschen Gütersloh, 1997 (Studien zum Verstehen fremder Religionen, 9), p. 142-179.

-, 'Greek ritual purity: from automatisms to moral distinctions', in P. ROESCH, U. SIMON (eds.), How purity is made, Wiesbaden 2012, p. 123-139.

COLE, S.G., 'The uses of water in Greek sanctuaries', in R. HÄGG, N. MARINATOS, G.C. NORDQUIST (eds.), Early Greek cult practice. Proceedings of the Fifth International Symposium at the Swedish Institute at Athens, 26-29 June, 1986, Stockholm, 1988 (ActaAth-4 , 38), p. 161-165.

CUMONT, F., Les Religions orientales dans le paganisme romain, Paris, 1929.

DILLON. M., 'The didactic nature of the Epidaurian Iamata', ZPE 101 (1994), p. 239-260.

DODDS, E.R., The Greeks and the irrational. Los Angeles/London, 1951.

DRESCHER, J., Apa Mena: a selection of Coptic texts relating to St. Menas, Cairo, 1946.

DÖRING, K., 'Antike Theorien über die staatspolitische Notwendigkeit der Göterfrucht', in Antike und Abendland 24 (1978), p. 43-56.

EDELSTEIN, L., 'Antike diätik', Die Antike 7 (1931), p. 255-270.

EDELSTEIN, E.J., EDELSTEIN, L., Asclepius. A collection and interpretation of the testimonies. 2. Interpretation. Baltimore, 1945

EHRENHEIM (VON), H., Greek incubation rituals in Classical and Hellenistic times, Liège, 2015 (Kernos, suppl. 29).

VAN DER EIJK, P., Medicine and philosophy in Classical antiquity. Doctors and philosophers on nature, soul, health and disease, Cambridge, 2005.

GAMMERL, B., 'Emotional styles - concepts and challenges', Rethinking history 16:2 (2012), p. 161-175. GINOUVÈs, R., Balaneutikè. Recherches sur le bain dans l'antiquité grecque, Paris, 1962 (BÉFAR, 200).

—, 'L'eau dans les sanctuaires médicaux', in P.J. VAN DER EIJK, H.F.J. HORTSMANSHOFF, P.H. SCHRIJVERS (eds.), Ancient medicine in its socio-cultural context. Papers read at the Congress held at Leiden University 13-15 April 1992, vol. 2, Amsterdam, 1994, p. 237-246.

GRAF, F., Apollo, London, 2009 (Gods and heroes of the ancient world).

GRENSEMANN, H., Die hippokratische Schrift 'Über die heilige Krankheit', Berlin, 1968 (Ars Medica, 2:1).

GRMEK, M.D., Diseases in the ancient Greek world, translated by M. Mueller and L. Mueller, Baltimore, 1989 (original edition Les Maladies à l'aube de la civilisation occidentale, 1983).

HANKINSON, R.J., Cause and explanation in ancient Greek thought, Oxford.

HERZOG, R., Die Wunderheilungen von Epidauros. Ein Beitrag zur Geschichte der Medizin und der Religion, Leipzig, 1931 (Philologus, suppl. 22:3).

JONES, W.H.S., Hippocrates (Loeb Classical Library), 1923-1931.

JONES, C.P., 'Stigma: Tattooing and Branding in Graeco-Roman Antiquity', JRS 77 (1987), p. 139-155.

KAMEN, D., 'A corpus of inscriptions: representing slave marks in antiquity', Amer. Acad. Rome 55

(2010), p. 95-110. 


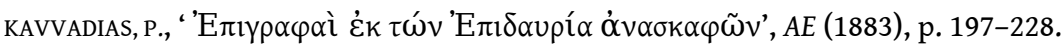

KINDT, J., 'Personal religion: a productive category for the study of ancient Greek religion?', JHS 135 (2015), p. 35-50.

KLEINMANN, A., Patients and healers in the context of culture: an exploration of the borderland between anthropology, medicine, and psychiatry, Berkeley, 1980.

KUDLIEN, F., ‘Early Greek primitive medicine', Clio Medica 3 (1968), p. 305-336.

—, 'Beichte und Heilung', Medizinhistorisches Journal 13, 1978, p. 1-14

LAMBRINOUDAKIS, V., 'L'eau médicale à Epidaure', in R. GINOUVÈS, A.-M. GUIMIER-SORBETS, J. JOUANNA, L. VILLARD (eds.), L'eau, la santé et la maladie dans le monde grec, Paris, 1994 (BCH, suppl. 28), p. 225236.

LATTE, K., 'Schuld und Sünde in der griechischen Religion', ARW 20 (1920-21), p. 254-298.

-, 'IG IV².1 ed. Hiller von Gaertringen', Gnomon 7 (1931), p. 113-135.

LIDONNICI, L.R., The Epidaurian miracle inscriptions. Text, translation and commentary, Atlanta, 1995

(Texts and translations, Graeco-Roman religion series, 36/11).

LLOYD, G.E.R., Magic, reason and experience, Cambridge, 1979.

-, In the grip of disease. Studies in the Greek imagination, Oxford, 2003.

LONGRIGG, J., Greek rational medicine. Philosophy and medicine from Alcmaeon to the Alexandrians,

London/New York, 1993.

MCNAMARA, L., 'Conjurers, purifiers, vagabonds, and quacks? The clinical roles of the folk and

Hippocratic healers of Classical Greece', Iris: Journal of the Classical Association of Victoria 16-17

(2003-2004), p. 2-25.

MÜLLER, H., 'Ein Heilungsbericht aus dem Asklepieion von Pergamon', Chiron 17 (1987), p. 193-233.

NISSEN, C., Entre Asclépios et Hippocrate. Étude des cultes guérisseurs et des médecins en Carie, Liège, 2009

(Kernos, suppl. 22).

NOCK, A.D., 'Pettazoni, Confessione dei peccati', Gnomon 15 (1939), p. 18-23.

OBERHELMAN, S., 'Introduction: medical pluralism, healing, and dreams in Greek culture', in S. OBERHELMAN (ed.), Dreams, healing and medicine in Greece from Antiquity to the present, Farnham, 2013.

PARKER, R., Miasma: Pollution and purification in early Greek religion, Oxford, 1983.

PEELS-MATTHEY, S., 'Moral purity in the Athenian theatre', in J.-M. CARBON, S. PEELS-MATTHEY (eds.), Purity and purification in the ancient Greek world. Texts, rituals, norms, Liège, 2018 (Kernos, suppl. 32), p. 93-109.

PERDRIZET, P., ‘La miraculeuse histoire de Pandare et d'Échédore', ARW 14 (1911), p. 54-129. PETROVIC, A., PETROVIC,I., Inner purity and pollution in Greek religion, vol. 1: Early Greek religion, Oxford, 2016

PETTAZZONI. R., La confessione dei peccati 1-3, Bologna 1929-1936, 'Grecia' in vol. 3, p. 163-220.

PETZL, G., Die Beichtinschriften Westkleinasiens, Bonn, 1994.

POHLENZ, M., Hippokrates und die Begründung der wissenschaftlichen Medizin, Berlin, 1938. 
RAMSEY, M., Professional and popular medicine in France, 1770-1830: The social world of medical practice, Cambridge, 1988.

REDDY, W., The navigation of feeling: A framework for the history of emotions, Cambridge, 2001.

RENBERG, G., Where dreams may come. Incubation sanctuaries in the Greco-Roman world, vols. 1-2, Leiden/Boston, 2016 (RGRW, 184).

ROBERTSON, N., 'The concept of purity in Greek sacred laws', in Chr. FREVEL, chr. NIHAN (eds.), Purity and the forming of religious traditions in the ancient Mediterranean world and ancient Judaism, Leiden/ Boston, 2013, p. 195-244.

ROHDE, E., Seelenkult und Unsterblichkeitsglaube der Griechen, Freiburg, 1894.

ROSCHER, W., 'Die "Hundekrankheit” ( $\kappa u ́ \omega v)$ der Pandareostöchter und andere mythische Krankheiten. Ein Beitrag zur Kritik der Mythen-Überlieferung', RhM 53 (1898), p. 169-204.

ROSENWEIN, B., Emotional communities in the early Middle Ages, Ithaca, 2006.

VERNANT, J.P., Les origines de la pensée grecque, Paris, $1969^{2}$.

VERSNEL, H.S., Inconsistencies in Greek and Roman religion. 1, Ter unus: Isis, Dionysos, Hermes: three studies in henotheism, Leiden, 1990.

-, Coping with the gods. Wayward Readings in Greek theology, Leiden/Boston, 2011 (RGRW, 173).

VEYNE, P., Les Grecs ont-ils cru à leurs mythes? Essai sur l'imagination constituante, Paris, 1983.

VILLARD, L., 'Le bain dans la médecine hippocratique', in R. GINOUVÈs, A.-M. GUIMIER-SORBETS, J. JOUANNA, L. VILLARD (eds.), L'eau, la santé et la maladie dans le monde grec (BCH, suppl. 28), Paris, 1994, p. 41-60. WICKKISER, B., Asklepios, medicine, and the politics of healing in fifth-century Greece, Baltimore, 2008. ZHMUD, L., The origin of the history of science in Classical Antiquity, Berlin/New York, 2006 (Peripatoi. Philologisch-historische Studien zum Aristotelismus, 19).

\section{NOTES}

1. Hdt. 4.90, Hippoc. Epid. 5.9 (Littré 5.208 bottom), Paus. 5.5.11, Nic. Alex. 253; Hom. Il. 9.446; Aesch. fr. 45 (TrGF 3); Il. 1.37-54; Soph. OT 22-39; Ar. fr. 58 (Austin, CGFP); Pl. Lg. 716D-E; Hippoc. Morb. Sacr. (ch.1, Littré vi.362; chapter 4 Jones); Od. 11.198-201.

2. This scholarly view is among other things founded on a statement of Celsus ( $1^{\text {st }}$ century AD), who describes how his own culture perceived the cause of disease before the birth of science: "illnesses were seen as caused by the anger of the immortal gods" (Celsus, Med. Book 1, preface, p. 4: morbos [...] ad iram deorum immortalium relatos esse). Thus, already in antiquity there existed a belief that the perception of causality of disease was evolving towards a more scientific explanation. See e.g. LONGRIGG (1993), p. 11 and 29; HANKINSON (1998), p. 51-54; BYNUM (2008), p. 79. Most researchers find one most common causality of disease in the ancient world, and the one of divine punishment is prominent. More cautious: PARKER (1983), p. 239, arguing that disease is on occasion explained as divine retribution. Cf. KINDT (2015), p. 46, quoting the opposition towards this view on causality of disease being divine punishment evidenced in Hippoc. Morb. Sacr. 5.1-4, 21.1-8.

3. For this shift as seen in shame turned into guilt as an internalized notion with the individuality forwarded by the sophistic, see LATTE (1920/21). 
4. DoDDs (1951), p. 28-63, esp. p. 31-37, 151-152. Internalization of emotion is an explanatory tool developed by S. Freud, adapted for the well-to-do in fin-de-siècle Vienna. Strong caution must, of course, be advised against using Freudian analysis on historical Greece.

5. See PETTAZzoni (1929-1936), passim, e.g. vol. 2(1), (1935), p. vii-xi, and BENDLIN (2001), p. 129, cf. ASSMAN (1999). Bendlin calls the separation of shame cultures and guilt cultures a product of Western imagination.

6. Herzog and Kavvadias lean towards one single redaction: HERZOG (1931), p. 58, KAVVADIAS (1883), p. 220. LiDonnici believes that a series of redactions made by the priests of the sanctuary would better account for the haphazard compositional nature of the collection: LIDONNICI (1995), p. 66. See also LIDONNICI (1995), p. 17 (date of the inscriptions with complete references), p. 50-75 on their compositional history (the iamata as a collection of votive tablets at the site and oral traditions).

7. IG IV 2 1, 121-124. Translations are available in HERZOG (1931) and LIDONNICI (1995). In this paper I use the translations of LiDonnici, unless otherwise stated. I also use the enumeration of LiDonnici, marking first which stele the iama comes from (A-D, equivalent to 121-124 of the IG), and then following the numbers from 1 to 70 , not starting the enumeration anew for each stele. None of the iamata would probably be older than the $5^{\text {th }}$ century BC: LIDONNICI (1995), p. 82. The votive tablets may have been both inscribed and pictorial, or the iama can be an explanation for an original votive, such as the silver pig in iama A4: LIDONNICI (1995), p. 50-51.

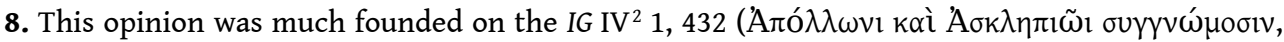
"To Apollo and Asclepius the forgiving...") of AD 306 and Plut. Superst. 168c, where godly pardon is vital to the recovery from disease: LATTE (1931), p. 132. These two testimonia are of Roman Imperial time (and in De superstitione, the argument is rebuked by the author), and should be used with caution when interpreting the iamata from Epidauros of Classical time.

9. NOCK (1939), p. 19, referring to the story of Amphimnastos, iama C47 (see discussion of this below). Further DODDS (1951), p.116, makes the case for Aristides inflicting some sort of selfpunishment in the harsh cures that he is ordained by Asklepios. It is difficult to say whether Aristides was ordained harsh cures or not, compared with other worshippers. v. BOUDON (1994), p. 167, writes that the cures prescribed to Aristides did not differ much from cures recommended by Galen, and thus were not out of the ordinary. Further it is pure speculation on our behalf to say that harsh cures (at least thought to be so by Aristides) were the result of Aristides feeling guilty - might it not just as well have been an effect of him declaring his devotedness to Asklepios?

10. KUDLIEN (1978), p.6. He sees the confessions as perhaps accredited to oriental influence, possibly from the priests putting the miracles together. He cannot, although the confession is present, see anything of the "forced confession" seen by NOCK (1939), p. 19.

11. The Edelsteins (EDELSTEIN - EDELSTEIN [1945], p. 113-118) write that Asklepios became so popular because his cult lay closer to religious thoughts prevailing in Hellenistic and Roman times. They further explain the success of the cult of Asklepios as one following the lay medicine that came to acknowledge the importance of curing both the body and the mind (ibid., p. 126-127; cf. also EDELSTEIN [1931]). For emphasis on purity of mind in contemporary medical texts, they refer to the Diocles $\left(4^{\text {th }}\right.$ century $\left.\mathrm{BC}\right)$ and Athenaeus $\left(1^{\text {st }}\right.$ century $\left.\mathrm{AD}\right)$. In the former text physical exercise is mentioned as important, but it has been complemented by "mental" exercises such as reading and studying in the Athenaeus. The point is that health is no longer only ascribed to a good physical state, but is more and more seen as a balance between physical and mental factors. Further they emphasize that Asklepios also followed a general trend in the ancient world that put more emphasis on ethical values, the "pure mind".

12. I use the term "sacred law" for lack of a better phrase. On the problematic concept of these cultic regulations, see CARBON - PIRENNE-DELFORGE (2012). Sacred laws stressing the importance of a 
pure mind: SEG 43.710 ( $1^{\text {st }}$ century AD); IG $\mathrm{II}^{2}, 1366$ (= LSCG $55=$ SEG 39.153, cult of Men) ( $1^{\text {st }}$ century AD); IG II ${ }^{2}, 1369$ = LSCG 53 (end $2^{\text {nd }}$ century AD); IG XII, 1, 789 = LSCG 139 (Hadrianic). For this group of sacred laws, see WÄCHTER (1910), p. 8-9; BREMMER (2002), p. 107; CHANIOTIS (2012), p. 131-133.

13. Translation: PEELS-MATTHEY (2018), p. 93. See also this article passim for an in-depth contextualization and analysis of hosios in relation to hagnos.

14. To J. BREMMER (2002) the edition of BOUfFARTIGe (1979) is the most reliable. Bouffartige shows that Porphyry, when citing Theophrastus, always makes a note of this, and this is not done concerning the Epidaurian inscription. Cf., though, CHANIOTIS (2012), p. 128 n. 27, concluding that the metrical text/verse was inscribed on the temple in Epidauros when it was built around 340 BC. ROBERTSON (2013, p. 230 n. 132), is indecisive on the original date of the inscription, but finds the suggested new date of Bremmer (the turn of the millennium) too late.

15. Examples of this type of mentality is found in Philostratus' Vita Apollonii 1.10 (a rich man

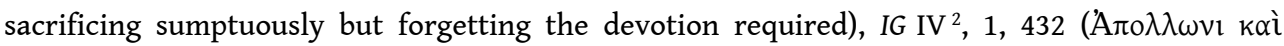

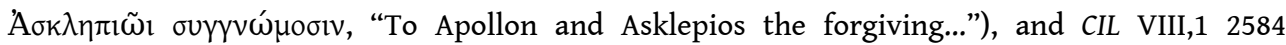
(Asklepieion at Lambaesis, Africa: Bonus intra, melior exi, "Enter a good man, leave a better one").

16. Hdt. 4.90, Hippoc. Epid. 5.9 (Littré 5.208 bottom), Paus. 5.5.11, Nic. Alex. 253. See further ROHDE (1894), p. 294-303; BURKERT (1985), p. 77; PARKER (1983), p. 208 (certain skin diseases).

17. PARKER (1983), p. 219, n. 67 with further references.

18. Hom. Il. 9.446; Aesch. fr. 45 (TrGF 3); Herodas 4.17-18. See the discussion in PARKER (1983), ch. 7 and esp. p. 216 and 225.

19. Given the biblical status of Homer in Classical Greece, it is not unlikely that this perceived causality was still prevalent at that time. For more examples in myth of gods punishing with illness: ROSCHER (1898), p. 169-204; cf. Pl. Phdr. 244d-e.

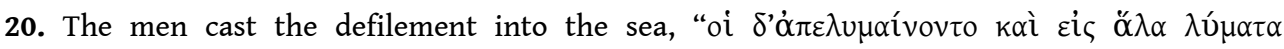
$\beta \alpha ́$ $\lambda \lambda$ ov..." It is not clear if they purified themselves because they had had a disease in the camp, or because it was the normal purification before a sacrifice. PARKER (1983, p. 217) believes the purification is a preliminary to the sacrifice.

21. Cf. Od. 11.198-201, and further LLOYD (2003), p. 17.

22. The purification in the sea was more likely a purification before the sacrifice, and not a method of removing a pollution held to be the cause of the plague. In any case, the way of appeasing the angered god is to offer a sumptuous sacrifice.

23. In any case, epic and tragedy are not necessarily an accurate reflection of the mentality of the so-called "popular religion", as has been showed by PARKER (1983), ch. 8, esp. p. 243.

24. See LLOYD (2003), p.90: "Tragedy is all about the gods and prophecies fulfilled..." On Sophocles, his experience of the plague 430-429, and his sponsoring of the introduction of Asklepios in Athens, see LLOYD (2003), p. 84-85.

25. Another early example is Lysias 6.1-2, where punishment by disease is inflicted upon persons having offended the gods. Here, though, the cause for the punishment by disease is offending the gods. Lys. 6.1-2: “... he tied up the horse to the knocker on the temple door, as though he were handing it back; but on the following night he contrived to take it away. Well, the man who did this has perished by the most painful death, of hunger..." (translation W.R.M. Lamb, Loeb 1943).

26. Ar. fr. 58 (Austin, CGFP).

27. See e.g. NISSEN (2009), p. 58-60.

28. See discussion on this in LLOYD (2003), p. 41-43. On the Sacred Disease is generally thought to have been written either at the end of the $5^{\text {th }}$ century, or the beginning of the $4^{\text {th }}$ century BC. See JONES (1923-31), vol. 2, 134 (Loeb Classical Library); POHLENZ (1938), p. 35; BOURGEY (1953), p. 75-76; GRENSEMANN (1968), p. 7-31 and the discussion in LLOYD (1979), p. 15.

29. Hippoc. Morb. sacr. ch. 1 (Littré vi.362), ch. 4 (Jones). 
30. Morb. sacr. ch. 1 (Littré vi.360-362), ch. 4 (Jones).

31. Esp. 14 and with the comments on this work in ZHMUD (2006), p. 55. See also BARTON (2005).

32. Hes. Op. 101-104: "The earth is full of evils and the sea is full. Some diseases come upon men by day and some by night: they roam of their own free will, bringing evils to mortals, silently, since wise Zeus took away speech from them." Attempts have been made at seeing disease as caused by sin here, because Prometheus did not obey the will of Zeus (KUDLIEN [1968], p. 315-316), but PARKER (1983), p. 241, convincingly argues that "the myth's ethos is that of the just so-story, not the theodicy", and that Greeks would never seriously have blamed Prometheus for all the diseases of the world. Cf., though, LLOYD (2003), p. 21.

33. GRAF (2009).

34. On the cult of Asklepios, its origin, spread, popular appeal, connection with the Hippocratic school, and the ritual of incubation, see WICKKISER (2008), NISSEN (2009), EHRENHEIM (2015), and RENBERG (2017).

35. DILLON (1994), p. 243 and 253. See LIDONNICI (1995), p. 18, for the function of the iamata to heighten the expectations of the worshippers and get them in the right mood for experiencing miracles.

36. See supra n. 4. Nos. C49-D70 are too fragmentary to use.

37. Cf. CHANIOTIS (1997), p. 152-153.

38. KUDLIEN (1978), p. 6; CHANIOTIS (1997), p. 152-153, and VERSNEL (2011), p. 295 and 415.

39. HERZOG (1931), p. 31.

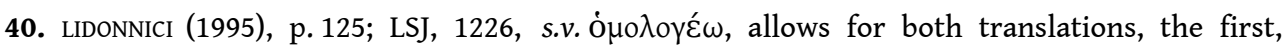
"agree", being the most common (2 and 3), and "confess" much less so (also 2).

41. The seven are A7, A11, B22, C47 ("worshippers who do not follow the cult rules") and A3, A4, and B36 ("worshippers who do not believe in the power of the god").

42. The translation is not entirely clear. These could be slave marks or marks of soldiers. See the discussions in PERDRIZET (1911) and LIDONNICI (1995), p. 91, n. 15-16. On slave tattoos in the ancient world, see JONES (1987) and KAMEN (2010).

43. LIDONNICI (1995), p. 121 (also for the edition of the Greek text chosen above); CHANIOTIS (2012), p. 130.

44. Cf. Petrovic - Petrovic (2016), p. 5-6, n. 16, on this iama as an example that the man did not adhere to the request in the Theophrastus inscription, that worshippers should arrive in a state of inner purity. Certainly, the connection between pure thoughts and belief in the divine is well made, but in the case of the iamata, there is also the aspect of not doubting the power of the god.

45. Cf. CHANIOTIS (2012), p. 130-133.

46. The story about the cup seems to be part of common Mediterranean folklore (or broken crockery being a common occurrence), as a similar story (but with silver plates) appears in the Early Christian Menas miracle no. 3 (DRESCHER [1946]).

47. Iama A15.

48. On pathology as reflected and understood in literature in ancient Greece, see e.g. GRMEK (1989), p. 17-46. On the Hippocratic conception of disease, see e.g. GRMEK (1989), p. 284-304. See further, on Hippocratic theoretical causality, established experience, and the method of dietetics, VAN DER EIJK (2005), p. 74-100.

49. Cf. Hippoc. Morb. 4.596-600, on different intestinal worms, and how the patient should be cleaned of them.

50. Cf. Theophrastus Hist.pl. 7.6.2, recommending the juice of a lettuce plant against dropsy and Hippoc. Aff. 246 (36) (medications that clean out water). However, surgical removal of excessive water seems to have been practised as well: "XXVII. Whenever cases of empyema or dropsy are treated by the knife or cautery, if the pus or water flow away all at once, a fatal result is certain" (Hippoc. Aph. 27). 
51. See Hippoc. Off. (In the Surgery), 1-6, on the layout of the operating room, equipment, and assistants.

52. Bath in cold water: (pond, river) B37, C53. Bath in bath-house (not stated whether prescription or just cleanliness, seems more probable to be the latter): iama C65. This can be compared with prescriptions given by Asklepios during incubation dreams to take baths in other sources: Aristid. Or. sacr. 1.7, 1.8, 1.18, 1.20-21, 1.34, 1.50, 3.6 and 5.22-24; baths in warm source: 1 , Cold baths (river, source, sea, snow): 16; not to bathe: 11 . Cf. also Marcus Antonius, In semet ipsum 5.8 (= M. Aur. Med. 5.8, EDELSTEIN - EDELSTEIN [1945] T407), on Asklepios giving cures such as cold baths. Cf. also the archaeology of bathing and possible water cures: GINOUVÈs (1962), p. 349-361; GINOUVÈS (1994); COLE (1988); BOUDON (1994), p. 163; LAMBRINOUDAKIS (1994).

53. See e.g. PARKER (1983), p. 207-211, esp. 211.

54. See VILLARD (1994), p. 48-52 on baths in the Hippocratic writings. E.g. Hippoc. Aff. 212 (4), vapour baths to thin out phlegm; Aff. 264 (53): excessive bathing can moisten the body too much and lead to fainting; Vict. 2.57 (On Regimen): on the properties of different types of baths. See further BOUDON (1994), p. 167-168. See also Galen, On the causes if disease, e.g. translated by Mark GRANT, Galen on food and diet, London/New York 2000, p. 46-61, where it is stated that disease occurs from imbalance in the hot and cold / dry and moist.

55. I. Cret. I xvii 19.

56. Galen, De simplicium medicamentorum temperamentis ac facultatibus 11.26 (12.345 K); CHANIOTIS (1995), p. 335.

57. I.Cret. I, XVII, 11A (1. 4-13); 11B, 12A-B, 14A, 17-20 (EDELSTEIN - EDELSTEIN [1945] testimonia 439441).

58. See the argumentation in MÜLLER (1987), p. 194-199.

59. MÜLLER (1987), p. 194-199.

60. Diet: Arist. Or. 47.45, 49.6, 49.24, 49.34, 49.35 and 49.37; drugs: 48.13; poultices: 49.25; bloodletting: 48.47; baths: Or. sacr. 1.7, 1.8, 1.18, 1.20-21, 1.34, 1.50, 3.6 and 5.22-24. As remarked by LLOYD (1979), p. 41, even if Asklepios' cures are reminiscent of medical cures, the cures of the god are deemed infallible.

61. NISSEN (2009), p. 42, 61.

62. As has been remarked by LLOYD (1979), p. 40-41.

63. Excepting iama B36, the man who laughed at Asklepios and was hurt in a riding accident.

64. For the concept of cultural groups within a larger society, see e.g. International Encyclopedia of the Social and Behavioral Sciences, 2001, s.v. Groups, The Sociology of, p. 6434-6439 [J. LINDENBERG] and s.v. Group Processes, The Social Psychology of, 6417-6423 [M.A. HOGG]. The definition may be compared with the notion of different emotional groups within a larger group, argued by REDDY (2001), ROSENWEIN (2006) and GAMMERL (2012).

65. VEYNE (1983), passim, esp.p. 11 and 33. More developed, on this subject, see also VERSNEL (1990), passim and VERSNEL (2011), p. 87, 148, 217 and 259.

66. OBERHELMAN (2013), XV.

67. LLOYD (1979), esp. p. 295-296 and 421-422; KLEINMAN (1980); RAMSEY (1988); MCNAMARA (20032004), p. 2-25; LLOYD (2003), p. 40-83; OBERHELMAN (2013), p. XV-XVi (with enlightening discussion and more references on the subject). 


\section{ABSTRACTS}

This paper analyses the cause of disease as perceived in Classical and Hellenistic Greece, and in particular in the iamata of Epidauros, cure inscriptions collected and set up in the sanctuary of Asklepios at Epidauros in $350 \mathrm{BC}$, some of which date back to $c .450 \mathrm{BC}$. It is concluded that the iamata reflect a plurality of explanations of disease that co-existed in ancient Greece and complemented each other.

L'article analyse la cause des maladies telle qu'elle était perçue dans la Grèce classique et hellénistique, et en particulier dans les iamata d'Épidaure, des récits de guérison rassemblés et présentés dans le sanctuaire local d'Asclépios vers 350 avant notre ère (certains récits pouvant remonter au milieu du siècle précédent). Ces iamata reflètent une pluralité d'explications qui coexistaient en Grèce ancienne et se complétaient mutuellement.

\section{AUTHOR}

\section{HEDVIG VON EHRENHEIM}

Uppsala University, Department of Archaeology and Ancient History

hedvig.vonehrenheim@antiken.uu.se 